\title{
Selected psychometric aspects of the Polish version of the Liverpool Self-efficacy Scale
}

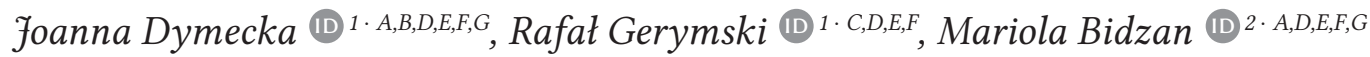 \\ 1: Department of Health Psychology and Quality of Life, Institute of Psychology, Opole University, Opole, Poland \\ 2: Department of Clinical Psychology and Neuropsychology, Institute of Psychology, University of Gdansk, Gdansk, Poland
}

\section{BACKGROUND}

Self-efficacy expresses the individual's belief in their ability to take up and continue actions in order to achieve a particular result and cope with various life events. For people with multiple sclerosis (MS), self-efficacy is an important resource because it affects how they adapt to the disease, and influences their motivation, health-related behavior and physical activity. It also has a great impact on their quality of life. Because of the lack of tools for measuring self-efficacy in Polish patients with multiple sclerosis, the goal of the current study was to develop a Polish language version of the Liverpool Self-efficacy Scale (LSES) and assess its validity and reliability.

\section{PARTICIPANTS AND PROCEDURE}

A total of 175 people diagnosed with MS took part in the study. A Polish version of the LSES, the Sense of Coherence Questionnaire (SOC-29), the Resiliency Assessment Scale (SPP-25), the Health-Related Hardiness Scale (HRHS), the Acceptance of Illness Scale (AIS) and the Multiple Sclerosis Impact Scale were applied.

\section{RESULTS}

Confirmatory factor analysis, reliability analysis using $\alpha$ and $\omega$ coefficients, and two measures of validity (content and criterion validity) were used in order to validate psychometric properties of the Polish version of the LSES. Our analyses confirmed a good fit of the one-factor and twofactor models.

\section{CONCLUSIONS}

The results indicate that the Polish version of the LSES is a useful and valuable tool for assessing levels of self-efficacy in Polish patients with multiple sclerosis. The scale can be used for both clinical and research purposes.

\section{KEY WORDS}

multiple sclerosis; personal resources; self-efficacy; psychometric validation

Corresponding AUthor - Rafał Gerymski, Department of Health Psychology and Quality of Life, Institute of Psychology, Opole University, 1 Staszica Square, 45-052 Opole, Poland, e-mail: rafal.gerymski@uni.opole.pl

AUthors' CONTRIBUtion - A: Study design · B: Data collection · C: Statistical analysis · D: Data interpretation .

E: Manuscript preparation · F: Literature search · G: Funds collection

to Cite this ARTICle - Dymecka, J., Gerymski, R., \& Bidzan, M. (2020). Selected psychometric aspects of the Polish version

of the Liverpool Self-efficacy Scale. Current Issues in Personality Psychology, 8(4), 339-351.

RECEIVED 15.04.2020 • REVIEWED 31.08.2020 • ACCEPTED 06.11.2020 • PUBLISHED 29.12.2020 


\section{BACKGROUND}

Self-efficacy is a central concept of Albert Bandura's (2001, 2007) socio-cognitive theory. It expresses the individual's belief in their ability to take up and continue actions in order to achieve a particular result and cope with various events in life (Bandura, 1977, 1982; Juczyński \& Juczyński, 2012; Luszczynska, Scholz, \& Schwarzer, 2005; Tomczak, 2009). Generally, it can be stated that a sense of self-efficacy refers to a person's opinion about their ability to act in a particular situation or when faced with a given task (Pervin \& John, 2001). A strong conviction of self-efficacy makes a person believe in their abilities, effectively deal with tasks and be optimistic and persistent in pursuing their goals. In the event of difficulties, a person with a high level of this variable will look for new solutions, will be motivated to act, will not be discouraged, and will adapt more easily to new, more difficult circumstances (Bandura, 1977, 1982, 1989, 2001; Byra, 2011; Kościelak, 2010; Kulik, 2008; Oleś, 2003; Schwarzer, 1997).

Self-efficacy, as a resilience resource, is also associated with other personal resources. Researchers indicate that although these resources are separate constructs, they have similar structures and significance for health and well-being (Antonovsky, 2005; Miciuk, Jankowski, \& Oleś, 2016; Posadzki, Stockl, Musonda, \& Tsouroufli, 2010). According to the theoretical background, self-efficacy is associated with sense of coherence (Antonovsky, 2005; Posadzki et al., 2010), which has been confirmed in multiple studies (Cassel \& Suedfeld, 2006; KröningerJungaberle \& Grevenstein, 2013; Li \& Shiu, 2008; Posadzki et al., 2010; Trap, Rejkjær, \& Hansen, 2015). Antonovsky (2005) indicated that people with a high level of self-efficacy feel that the effect of a certain behavior is valuable to them, which was associated with meaningfulness. In addition, they know that by behaving in a certain way, they will achieve the intended goal, which Antonovsky considers to be associated with comprehensibility. The researcher also indicated that a high level of self-efficacy is associated with knowing that a person was able to perform a certain activity successfully, which was associated with manageability. Moreover, many studies show a relationship between self-efficacy, psychological hardiness (Bernard, Hutchison, Lavin, \& Pennington, 1996; Chroni, Hatzigeorgiadis, \& Theodorakis, 2006; Hashemi, Kooshesh, \& Eskandari, 2015; May, Sowa, \& Niles, 1993; Oman \& Duncan, 1995) and resiliency (Alessandri, Vecchione, \& De Franceschi, 2008; Gilak, Zadehmohammadi, \& Bagheri, 2013; Milioni et al., 2015; Ogińska-Bulik \& Juczyński, 2010).

The above-mentioned features of self-efficacy make it a particularly important resource when dealing with a chronic disease. Patients with high self-efficacy are more effective in dealing with stress caused by illness, following medical recommendations, are more determined to take actions to improve their health and cope with pain better (Luszczynska et al., 2005; Schwarzer, 1997; Ziarko, 2014). One of the chronic diseases that pose a particular challenge to the adaptation process is multiple sclerosis (MS), a disease of the central nervous system that is the most common non-traumatic cause of disability in young people (Dymecka \& Gerymski, 2020). It is considered an acquired demyelinating disease of unknown cause and unpredictable course with multifocal, inflammatory demyelinating lesions occurring at different times and in different parts of the body, leading to a wide range of neurological symptoms such as paresis of the lower and upper limbs, ataxia and tremor, sensory disturbance, vision and sphincter control, problems with speech and swallowing, cognitive impairment, mood disorders, fatigue and chronic pain that cause a gradual increase in disability (Cross, Cross, \& Piccio, 2012; Członkowska, 2011; Dymecka \& Bidzan, 2018; Gold \& Wolinsky, 2011; Nowaczyk \& Cierpiałkowska, 2016; Podlecka-Piętowska, 2010; Selmaj, 2006; Zakrzewska-Pniewska, 2010).

Multiple sclerosis significantly hinders everyday functioning, fulfilling family, social, and professional roles, disturbs the emotional well-being of patients, significantly affects the quality of life and triggers a complex adaptation process (Carvalho et al., 2014; Ghafari, Fallahi-Khoshknab, Nourozi, \& Mohammadi, 2015; Hyarat, Subih, Rayan, Salami, \& Harb, 2019; Dymecka \& Gerymski, 2019; Irvine, Davidson, Hoy, \& Lowe-Strong, 2009; McReynolds, Koch, \& Rumrill, 1999; Vukusic \& Marignier, 2015), which is why self-efficacy is an important resource for this group of patients. It affects how they adapt to and manage the disease (Calandri, Graziano, Borghi, \& Bonino, 2019; Eccles \& Simpson, 2011; Motl \& Snook, 2008; Schmitt, Goverover, Deluca, \& Chiaravalloti, 2014; Wassem, 1992), physical activity and rehabilitation (Casey et al., 2018; Ferrier, Dunlop, \& Blanchard, 2010; Morris, McAuley, \& Motl, 2008; Motl \& Snook, 2008; Sikes, Cederberg, Baird, Sandroff, \& Motl, 2019) and the well-being and quality of life (Calandri, Graziano, Borghi, \& Bonino, 2018; Guicciardi, Carta, Pau, \& Cocco, 2019; Mitchell, Benito-León, Morales González, \& Rivera-Navarro, 2005; Motl, McAuley, Wynn, Sandroff, \& Suh, 2013; Motl \& Snook, 2008).

In connection with the recognition of the importance of self-efficacy for coping with multiple sclerosis and the fact that this disease has many features that do not occur in other chronic diseases, the need for a scale measuring the level of self-efficacy specific for this group of patients was recognized (Bonino et al., 2018; Seebacher et al., 2019). One of the first questionnaires examining the level of this variable in people with MS, following the scale proposed by Schwartz and colleagues (1996), is the Liverpool Self-efficacy Scale (LSES; Airlie, Baker, Smith, \& Young, 2001). 


\section{DESCRIPTION OF THE ORIGINAL SCALE}

The Liverpool Self-efficacy Scale is a short scale based primarily on the opinions of patients. It consists of two domains: control (6 items) and personal agency (5 items). In the original version of the scale, both LSES subscales are additive and can form one summary score. The person tested can relate to 11 test items according to a 4-point scale ranging from 1 (definitely agree) to 4 (definitely disagree). Some test items contain reverse scoring. The higher the score, the higher the patient's self-efficacy. The reliability of the scale was confirmed using Cronbach's $\alpha$ analysis of internal consistency $(\alpha=.81)$. To assess the scale's construct validity the authors used scales that measure disability and dependence - Barthel (Collin, Wade, Davis, \& Horne, 1988) and Rankin (1957) scales; and also questionnaires that measure the levels of personal resources - Self-Esteem Scale (Rosenberg, 1965) and Mastery Locus of Control (Pearlin \& Scholler, 1978).

The psychometric analysis of the scale showed that it is an accurate and reliable tool and can be used to study the sense of self-efficacy in people with multiple sclerosis. The purpose of the current research was to develop the Polish language version of the Liverpool Self-efficacy Scale and to analyze its selected psychometric aspects, as well as to assess its suitability for determining the level of self-efficacy in people with MS.

\section{POLISH LANGUAGE VERSION OF THE SCALE}

The language analysis of the scale was carried out in accordance with the guidelines. Two independent translators who are also psychologists translated the scale into Polish. Then, the translations were analyzed and one Polish version of the LSES scale was created, which was passed on to persons with vocational, secondary, and higher education in order to identify any ambiguities in the wording. The next step was for the unified Polish version of the scale to be translated back into English ('back translation') by a native speaker who did not know the original language version in order to ensure the accuracy and equivalence of both versions (English and Polish) of the scale. The reverse translation corresponds with the original version. The final version was used in the study.

\section{COURSE OF STUDY}

The research was carried out with the consent of the Ethics Committee at the Institute of Psychology of the University of Gdansk (No. 19/06/2015). The group studied consisted of patients diagnosed with MS who were on rehabilitation stays at the John Paul II Rehabilitation Centre for Individuals with Multiple Sclerosis in Borne Sulinowo, as well as people under the care of the association of MS Patients in Głogów and the Twardziele group (located in the GdanskGdynia-Sopot Tricity area). Patients with cognitive deficits which impeded the understanding of psychological questionnaires were excluded from the study (i.e., patients who scored more than 3 points on the Cognitive Disorders subscale of Guy's Neurological Disability Scale questionnaire). Before conducting the study, patients were asked to give their consent. They were informed of the purpose of the research and the fact that it was anonymous and all data would be confidential and only used for scientific purposes. All patients agreed to participate in the study, which consisted of them completing a set of several questionnaires. The study was usually conducted in a single meeting with the patient, with no time limit; the duration was adjusted to the psychophysical capacity of the respondents.

\section{PARTICIPANTS AND PROCEDURE}

\section{PARTICIPANTS}

The study group consisted of 175 patients diagnosed with multiple sclerosis. The study involved 94 women (53.7\%) and 81 men (46.3\%) aged 18 to $73(M=46.28$, $S D=12.6)$. Of the respondents, $1(0.6 \%)$ was in education, $2(1.1 \%)$ had primary education, 29 (16.6\%) had vocational education, $78(44.6 \%)$ had secondary education, 14 (8\%) had higher education - BA degree, and 51 (29.1\%) had higher education - MA degree. The average duration of the disease was 15.14 years (range 0-42). Sixty-two (35.4\%) people had relapsingremitting MS, 31 (17.7\%) - primary-progressive MS, $38(21.7 \%)$ - secondary-progressive MS, 10 (5.7\%) progressive with relapses, and $34(19.4 \%)$ - an unspecified form of MS.

\section{MEASURES}

The Liverpool Self-efficacy Scale (LSES; Airlie et al., 2001) was used to measure self-efficacy in people with multiple sclerosis. This scale is composed of two subscales: control (6 items) and personal agency (5 items). In the original version of the scale, both LSES subscales are additive and can form one summary score. Participants assess the 11 items on a 4-point Likert-like scale from 1 (I strongly agree) to 4 (I strongly disagree). Some items are reverse-scored. The higher the score, the higher the patient's sense of efficacy. This original version of the scale is characterized by high reliability (Cronbach's $\alpha=.81$ for the summary score). 
The Acceptance of Illness Scale (AIS; Felton, Revenson, \& Hinrichsen, 1984; Polish adaptation by Juczyński, 2001) was used to assesses patients' adaptation to limitations caused by illness. It contains 8 items describing consequences of poor health. Each item is assessed by the participant on a 5-level Likert-like scale ranging from 1 (I strongly agree) to 5 (I strongly disagree). A low score indicates lack of acceptance of the illness and a strong sense of psychological discomfort. A high score indicates acceptance of the illness and lack of negative emotions associated with it. The higher the acceptance of the illness, the better the adaptation to it. The reliability of the Polish version of the scale is satisfactory, with Cronbach's $\alpha=.85$.

The Multiple Sclerosis Impact Scale 29 (MSIS-29; Hobart, Lamping, Fitzpatrick, Riazi, \& Thompson, 2001; Polish adaptation by Jamroz-Wiśniewska et al., 2007) was used to measure the health-related quality of life (HRQoL). The scale consists of 29 questions: 20 regarding an individual's physical condition and 9 regarding their psycho-logical condition. Participants assess each of the items on a 5-step Likert scale. The higher the score, the greater the impact of MS on one's quality of life. An overall score, as well as scores on particular subscales, can be calculated. The reliability and validity of the Polish version of the scale are satisfactory. Cronbach's $\alpha$ coefficients were equal to .97 for the physical factor of quality of life and .94 for the psychological factor.

The Sense of Coherence Questionnaire (SOC-29; Antonovsky, 1987; Polish adaptation by Pasikowski, 2001) was used to measure the patients' sense of coherence. The questionnaire consists of 29 items which refer to different aspects of human life. Participants assess them on a 7-level semantic scale with bipolar extreme points. Some items are reverse-scored. The overall score is calculated by summing up the points from separate items. The questionnaire is used to measure global sense of coherence as well as its three components: comprehensibility, manageability, and meaningfulness. The reliability coefficient for the Polish version of the SOC-29 equals .88.

The Health-Related Hardiness Scale (HRHS; Pollock, 1986; Polish adaptation by Dymecka et al., 2020) for measuring psychological hardiness in people with health problems was also used. It contains 34 items which participants assess on a 6-point Likert scale ranging from 1 (complete disagreement) to 6 (complete agreement). Some items are reverse-scored. A participant may score between 34 and 204 points on the HRHS. The higher the score is, the higher is the level of health-related psychological hardiness. As well as overall levels of health-related psychological hardiness, the scale also measures its three components: control (14 items), commitment (7 items), and challenge (13 items). Cronbach's $\alpha$ for the original version of the HRHS was .91, for the control subscale was .81, for the commitment subscale was .62 and for the challenge subscale was .80 .

The Resiliency Assessment Scale (SPP-25; OgińskaBulik \& Juczyński, 2008) was used to measure patients' resiliency. It consists of 25 items forming 5 subscales measuring 5 factors: determination and persistence in action, openness to new experiences and sense of humor, personal competence, and tolerance for negative affect, tolerance for failures and treating life as a challenge, and optimistic attitude towards life and the ability to mobilize oneself in difficult situations. All items are assessed on a 5-level Likert-like scale ranging from 0 (strongly disagree) to 4 (strongly agree). Results are calculated for the whole scale and for the separate subscales. The higher the score is, the higher is the level of ego resiliency. This scale is characterized by high reliability (Cronbach's $\alpha=.89$ for the summary score).

Interviews with patients were conducted to determine biomedical variables such as the type of the disease, its duration, age at the time of diagnosis, disability level (EDSS), occurring symptoms, the ability to move independently, disease-modifying therapy, functioning in everyday life, use of rehabilitation, social support and general well-being. Respondents were also asked about socio-demographic variables such as age, gender, or education, marital status, place of living, education, family structure, professional activity and financial situation.

\section{RESULTS}

\section{DESCRIPTIVE STATISTICS}

The distributions of the measured variables were tested with the Shapiro-Wilk test. The test showed that some variables had non-normal distribution. However, the skewness and kurtosis values indicated a small asymmetry of the analyzed distributions (Kim, 2013). Due to the above information, parametric analyses were used for the purpose of this article.

We also verified differences between men and women in the level of the examined variables. Results obtained with the $t$-test did not reveal any significant differences in the level of variables tested (see Table 1).

\section{CONFIRMATORY FACTOR ANALYSIS}

The analysis showed a bad goodness of fit of the onefactor and two-factor models based on collected data (see Table 2). On the basis of modification indices, error covariances were set within personal agency subscale items -7 and 8,8 and 10, 9 and 11, and 10 and 11 . This allowed us to obtain good one-factor and two-factor models. These modifications had no 
semantic justification and were purely exploratory in nature. For detailed information, see Table 2.

Factor loadings analysis showed that items 3, 6, and 8 in a two-factor model had lower loading than other items from this subscale. Removing those items lowered the goodness of fit indicators, so it was decided to keep those items in future analyses. Detailed information can be found in Table 3 .

Table 1

Descriptive statistics and the results of gender comparisons of selected variables $(N=175)$

\begin{tabular}{|c|c|c|c|c|c|c|c|c|c|}
\hline & $M$ & Me & $S D$ & Min & Max & W & $p$ & SKE & K \\
\hline Self-efficacy - Summary & 27.65 & 27.00 & 5.88 & 11.00 & 41.00 & .99 & .393 & .12 & -.17 \\
\hline Self-efficacy - Control & 15.05 & 15.00 & 3.52 & 6.00 & 23.00 & .98 & .133 & .13 & -.33 \\
\hline $\begin{array}{l}\text { Self-efficacy - Personal } \\
\text { agency }\end{array}$ & 12.61 & 12.00 & 3.03 & 5.00 & 20.00 & .99 & .237 & .03 & -.18 \\
\hline Sense of coherence & 130.84 & 131.00 & 29.61 & 71.00 & 194.00 & .98 & .064 & .01 & -.82 \\
\hline Hardiness & 133.77 & 131.00 & 22.86 & 79.00 & 193.00 & .99 & .500 & .04 & -.01 \\
\hline Resilience & 70.26 & 71.00 & 15.10 & 19.00 & 100.00 & .98 & .119 & -.43 & .11 \\
\hline Acceptance of illness & 24.20 & 25.00 & 8.55 & 8.00 & 40.00 & .97 & .010 & -.08 & -.86 \\
\hline $\begin{array}{l}\text { MS' Influence on QoL - } \\
\text { Physical aspect }\end{array}$ & 51.62 & 51.00 & 19.33 & 20.00 & 97.00 & .97 & .008 & .33 & -.64 \\
\hline \multirow{3}{*}{$\begin{array}{l}\text { MS' Influence on QoL - } \\
\text { Mental aspect }\end{array}$} & 23.74 & 24.00 & 9.48 & 9.00 & 43.00 & .96 & .001 & .16 & -.95 \\
\hline & \multicolumn{2}{|c|}{ Men } & \multicolumn{2}{|c|}{ Women } & \multirow[t]{2}{*}{$t(173)$} & \multirow[t]{2}{*}{$p$} & \multirow[t]{2}{*}{$\mathrm{LLCl}$} & \multirow[t]{2}{*}{ ULCI } & \multirow{2}{*}{$d_{\text {Cohen }}$} \\
\hline & M & $S D$ & M & $S D$ & & & & & \\
\hline Self-efficacy - Summary & 27.26 & 6.17 & 28.09 & 5.56 & -0.83 & .410 & -2.83 & 1.16 & .14 \\
\hline Self-efficacy - Control & 14.79 & 3.62 & 15.34 & 3.40 & -0.91 & .364 & -1.74 & 0.64 & .16 \\
\hline $\begin{array}{l}\text { Self-efficacy - Personal } \\
\text { agency }\end{array}$ & 12.47 & 3.11 & 12.78 & 2.96 & -0.61 & .545 & -1.34 & 0.71 & .10 \\
\hline Sense of coherence & 128.49 & 28.32 & 133.52 & 31.02 & -0.99 & .324 & -15.05 & 5.01 & .17 \\
\hline Hardiness & 133.64 & 22.06 & 133.92 & 23.91 & -0.07 & .944 & -8.05 & 7.49 & .01 \\
\hline Resilience & 68.50 & 16.02 & 72.25 & 13.86 & -1.35 & .181 & -9.27 & 1.77 & .25 \\
\hline Acceptance of illness & 24.58 & 8.24 & 23.77 & 8.94 & 0.55 & .582 & -2.09 & 3.71 & .09 \\
\hline $\begin{array}{l}\text { MS'Influence on QoL - } \\
\text { Physical aspect }\end{array}$ & 51.59 & 20.02 & 51.66 & 18.68 & -0.02 & .984 & -6.64 & 6.51 & .01 \\
\hline $\begin{array}{l}\text { MS' Influence on QoL - } \\
\text { Mental aspect }\end{array}$ & 24.60 & 9.73 & 22.77 & 9.16 & 1.13 & .259 & -1.37 & 5.04 & .19 \\
\hline
\end{tabular}

Note. W - Shapiro-Wilk's test statistic, SKE - skewness, K - kurtosis.

Table 2

Results of the confirmatory factor analysis: goodness of fit measures $(N=175)$

\begin{tabular}{|c|c|c|c|c|c|c|c|c|}
\hline & \multirow[t]{2}{*}{$n_{\text {items }}$} & \multirow[t]{2}{*}{$\chi^{2}$} & \multirow[t]{2}{*}{$p$} & \multirow[t]{2}{*}{$\mathrm{CFI}$} & \multirow[t]{2}{*}{ TLI } & \multirow[t]{2}{*}{ RMSEA } & \multicolumn{2}{|c|}{ RMSEA $90 \% \mathrm{CI}$} \\
\hline & & & & & & & LLCl & ULCI \\
\hline Model with 1 factor & 11 & 113.00 & $<.001$ & .855 & .819 & .095 & .072 & .116 \\
\hline Model with 2 factors & 11 & 110.00 & $<.001$ & .860 & .821 & .094 & .073 & .116 \\
\hline Model with 1 factor \& error covariances & 11 & 70.70 & .002 & .936 & .911 & .066 & .039 & .091 \\
\hline Model with 2 factors \& error covariances & 11 & 69.90 & .002 & .935 & .908 & .067 & .041 & .092 \\
\hline
\end{tabular}


Table 3

Results of the confirmatory factor analysis: factor loadings for a two-factor model $(N=175)$

\begin{tabular}{|c|c|c|c|c|c|}
\hline Factor & Items $\mathrm{s}^{\mathrm{a}}$ & Estimate & SE & Z & $p$ \\
\hline \multirow[t]{6}{*}{ Control } & $\begin{array}{l}\text { 1. Since my diagnosis was confirmed, my life has been } \\
\text { beset with difficulties over which I have no control. }\end{array}$ & .67 & .07 & 9.21 & $<.001$ \\
\hline & 2. I feel in control of my life.* & .47 & .07 & 5.99 & $<.001$ \\
\hline & 3. I rely on others to help me make decisions. & $.28^{\mathrm{b}}$ & .07 & 3.41 & $<.001$ \\
\hline & 4. Sometimes I feel that my MS controls my life. & .71 & .07 & 9.98 & $<.001$ \\
\hline & 5. I often feel helpless when dealing with my difficulties. & .78 & .06 & 11.21 & $<.001$ \\
\hline & $\begin{array}{l}\text { 6. The way my MS will affect me in the future mostly } \\
\text { depends on me.* }\end{array}$ & $.29^{\mathrm{b}}$ & .09 & 3.57 & $<.001$ \\
\hline \multirow{5}{*}{$\begin{array}{l}\text { Personal } \\
\text { agency }\end{array}$} & 7. I worry about how I will cope in the future. & .65 & .08 & 8.67 & $<.001$ \\
\hline & $\begin{array}{l}\text { 8. Despite my difficulties, I still manage to cope with daily } \\
\text { life.* }\end{array}$ & $.25^{\mathrm{b}}$ & .07 & 3.04 & .002 \\
\hline & $\begin{array}{l}\text { 9. There is really no way I can solve some of the problems } \\
\text { I have with my MS. }\end{array}$ & .54 & .07 & 7.09 & $<.001$ \\
\hline & 10. Despite my MS, I can do anything I set my mind on.* & .50 & .07 & 6.29 & $<.001$ \\
\hline & 11. I am confident I can overcome my difficulties.* & .47 & .06 & 5.87 & $<.001$ \\
\hline
\end{tabular}

Table 4

Results of the reliability analysis $(N=175)$

\begin{tabular}{|c|c|c|c|c|c|}
\hline Factor & Items $^{\mathrm{a}}$ & M & $S D$ & $\alpha$ & $\omega t$ \\
\hline \multirow[t]{6}{*}{ Control } & $\begin{array}{l}\text { 1. Since my diagnosis was confirmed, my life has been beset } \\
\text { with difficulties over which I have no control. }\end{array}$ & 2.56 & 0.96 & .70 & .72 \\
\hline & 2. I feel in control of my life.* & 2.75 & 0.85 & & \\
\hline & 3. I rely on others to help me make decisions. & 2.50 & 0.85 & & \\
\hline & 4. Sometimes I feel that my MS controls my life. & 2.34 & 0.93 & & \\
\hline & 5. I often feel helpless when dealing with my difficulties. & 2.45 & 0.92 & & \\
\hline & $\begin{array}{l}\text { 6. The way my MS will affect me in the future mostly depends } \\
\text { on me.* }\end{array}$ & 2.79 & 1.07 & & \\
\hline \multirow{5}{*}{$\begin{array}{l}\text { Personal } \\
\text { agency }\end{array}$} & 7. I worry about how I will cope in the future. & 2.18 & 1.01 & .67 & .70 \\
\hline & 8. Despite my difficulties, I still manage to cope with daily life.* & 3.31 & 0.89 & & \\
\hline & $\begin{array}{l}\text { 9. There is really no way I can solve some of the problems I have } \\
\text { with my MS. }\end{array}$ & 2.54 & 0.93 & & \\
\hline & 10. Despite my MS, I can do anything I set my mind on.* & 2.31 & 0.86 & & \\
\hline & 11. I am confident I can overcome my difficulties.* & 2.63 & 0.84 & & \\
\hline
\end{tabular}

Note. ${ }^{*}$ Reversed items, ${ }^{a}$ items in Polish can be found in the Appendix, one-factor model reliability $-\alpha=.81, \omega \mathrm{t}=.82$.

\section{RELIABILITY}

Cronbach's $\alpha$ and McDonald's $\omega_{\text {total }}$ (Gerymski \& Krok, 2019, 2020; Ciżkowicz, 2018) were used to test the reliability of the scale. The lowest, but still acceptable, values were obtained for the personal agen- cy subscale. The control subscale was the one with the highest reliability. Removing any of the 11 items did not increase significantly subscales' reliability. The highest reliability was obtained for a one-factor model $\left(\alpha=.81, \omega_{t}=.82\right)$. For more detailed information, see Table 4. 


\section{VALIDITY}

The validity of the LSES scale was verified by two methods: the method of content validity and criterion validity. In order to verify the relevance of the LSES, the content validity ratio (CVR; Lawshe, 1975) was used. Ten researchers in the field of medicine and health psychology were asked to assess how essential scale items were to the whole scale. Before assessing the questions, judges were introduced to the theory of self-efficacy. CVR and CVI (content validity index) measures calculated from the obtained results present positive values. These results show that all items are accurate from the theoretical point of view and are essential to the whole scale. For more detailed information, see Table 5.

Criterion validity of LSES was measured using Pearson's $r$ correlation coefficient. It was decided to verify the relationship between Liverpool Self-efficacy Scale and other measures of personal resources - sense of coherence, hardiness, resiliency, acceptance of illness, and health-related quality of life. LSES summary score and its subscales were significantly and positively correlated with sense of coherence, hardiness, resilience, and acceptance of illness scores, and negatively with multiple sclerosis' influence on quality of life (QoL) scores. Effect size coefficients indicated moderate relationships between LSES scores and other tested constructs (see Table 6).

\section{DISCUSSION}

Due to the lack of questionnaires measuring the sense of self-efficacy in patients with MS, the purpose of the

Table 5

Results of validity analysis: CVR and CVI measures $(N=175)$

\begin{tabular}{|c|c|c|c|}
\hline Factor & Items ${ }^{\mathrm{a}}$ & CVR & $\mathrm{CVI}$ \\
\hline \multirow[t]{6}{*}{ Control } & $\begin{array}{l}\text { 1. Since my diagnosis was confirmed, my life has been beset with difficulties } \\
\text { over which I have no control. }\end{array}$ & .40 & .74 \\
\hline & 2. I feel in control of my life.* & .99 & \\
\hline & 3. I rely on others to help me make decisions. & .80 & \\
\hline & 4. Sometimes I feel that my MS controls my life. & .60 & \\
\hline & 5. I often feel helpless when dealing with my difficulties. & .99 & \\
\hline & 6. The way my MS will affect me in the future mostly depends on me.* & .80 & \\
\hline \multirow{5}{*}{$\begin{array}{l}\text { Personal } \\
\text { agency }\end{array}$} & 7. I worry about how I will cope in the future. & .60 & \\
\hline & 8. Despite my difficulties, I still manage to cope with daily life.* & .99 & \\
\hline & 9. There is really no way I can solve some of the problems I have with my MS. & .40 & \\
\hline & 10. Despite my MS, I can do anything I set my mind on.* & .60 & \\
\hline & 11. I am confident I can overcome my difficulties.* & .99 & \\
\hline
\end{tabular}

Note. * Reversed items, ${ }^{\text {a }}$ items in Polish can be found in the Appendix.

Table 6

Results of the validity analysis: Pearson's $r$ correlation $(N=175)$

\begin{tabular}{|c|c|c|c|c|c|c|}
\hline & \multicolumn{6}{|c|}{ LSES } \\
\hline & \multicolumn{2}{|c|}{ Summary score } & \multicolumn{2}{|c|}{ Control } & \multicolumn{2}{|c|}{ Personal agency } \\
\hline & $r$ & $p$ & $r$ & $p$ & $r$ & $p$ \\
\hline Sense of coherence & .56 & $<.001$ & .58 & $<.001$ & .42 & $<.001$ \\
\hline Hardiness & .35 & $<.001$ & .33 & $<.001$ & .30 & $<.001$ \\
\hline Resilience & .41 & $<.001$ & .39 & $<.001$ & .35 & $<.001$ \\
\hline Acceptance of illness & .53 & $<.001$ & .52 & $<.001$ & .42 & $<.001$ \\
\hline MS' Influence on QoL - Physical aspect & -.44 & $<.001$ & -.42 & $<.001$ & -.36 & $<.001$ \\
\hline MS' Influence on QoL - Mental aspect & -.56 & $<.001$ & -.57 & $<.001$ & -.42 & $<.001$ \\
\hline
\end{tabular}

Note. Correlation between Control and Personal agency: $r=.62, p<.001$. 
current research was to adapt the Polish version of the LSES scale. For this purpose, the confirmatory factor analysis, reliability analysis using $\alpha$ and $\omega$ coefficients and two measures of validity (content and criterion validity) were used on a sample of 175 patients. The Polish version of the scale turned out to be valid and reliable.

Our analyses did not confirm a good fit of the one-factor and two-factor models without using residual correlations. The LSES was found to be a reliable and valid scale. The $\alpha$ and $\omega$ coefficients exceed the .70 value, which indicates the consistency of the validated tool. These results are in agreement with the original version of the scale. Validity measured using CVR and CVI indicates that the scale items fit well into the concept of self-efficacy and personal resources.

The results presented above indicate a relationship between LSES scores and results on other scales measuring personal resources such as the sense of coherence, psychological hardiness and resilience, which is consistent with other studies analyzing the relationships between these variables (Alessandri et al., 2008; Krok \& Gerymski, 2019; Li \& Shiu, 2008; Posadzki et al., 2010; Trap et al., 2015) and with the theoretical assumptions of the authors of the presented constructs.

Although our study produced a reliable and valid scale, it is not free of limitations. Despite the fact that the tested sample meets the requirements of psychometric validation (at least $N=10$ per item), it is not representative. One hundred seventy-five people are only a small part of the population. What is more, the loading of some items is significantly lower in comparison to other scale items. It was decided to include these items in the analyses, because removing them did not increase model fit indicators and scale reliability. Additionally, it was not possible to obtain satisfactory values of the model fit coefficients without applying error covariances (which were not justified from the semantic point of view). What is more, our sample does not meet the recommended sample of 200 for confirmatory factor analysis (Gerymski \& Krok, 2019). Unfortunately, a larger sample of respondents could not be obtained. Bearing this in mind, we conducted the analysis with extreme caution. No statistical artefacts were detected.

Self-efficacy is an important resource in the course of dealing with chronic disease (Krok \& Gerymski, 2019). Due to the characteristics of MS, such as the unpredictability of its progression, the onset in early adulthood, the impact on work and family life, the possibility of severe disability and a wide range of symptoms, including cognitive disorders, mood disorders and fatigue, there is a need to measure the sense of self-efficacy in this group of patients using scales taking into account the specific nature of the disease. One such tool is the Liverpool Self-efficacy
Scale. It is a scale specific for MS, and data from studies showing the role of self-efficacy in MS indicate the particular importance of studying this variable in the population of people with MS. The results of the above analyses suggest that the Polish version of the Liverpool Self-efficacy Scale is a tool with satisfactory validity and reliability, but it requires further work on a much larger sample of MS patients.

\section{RefERENCES}

Alessandri, G., Vecchione, M., \& De Franceschi, I. (2008). Ego-resiliency, regulatory emotional selfefficacy beliefs and work performance: an empirical contribution. Risorsa Uomo, 14, 411-424.

Airlie, J., Baker, G. A., Smith, S. J., \& Young, C. A. (2001). Measuring the impact of multiple sclerosis on psychosocial functioning: The development of a new self-efficacy scale. Clinical Rehabilitation, 15, 259265. https://doi.org/10.1191/026921501668362643

Antonovsky, A. (1987). The salutogenic perspective: Toward a new view of health and illness. Advances, 4, 47-55.

Antonovsky, A. (2005). Rozwikłanie tajemnicy zdrowia. Jak radzić sobie ze stresem i nie zachorować [Unraveling the mystery of health: How people manage stress and stay well]. Warszawa: Instytut Psychiatrii i Neurologii.

Bandura, A. (1977). Self-efficacy. Toward a unifying theory of behavioral change. Psychological Review, 84, 191-215. https://doi.org/10.1037/0033295X.84.2.191

Bandura, A. (1982). Self-efficacy mechanism in human agency. American Psychologist, 37, 122-147. https://doi.org/10.1037/0003-066X.37.2.122

Bandura, A. (1989). Regulation of cognitive processes through perceived self-efficacy. Developmental Psychology, 25, 729-735. https://doi.org/10.1037/00121649.25.5.729

Bandura, A. (2001). Social cognitive theory: An agentic perspective. Annual Review of Psychology, 52, 1-26. https://doi.org/10.1146/annurev.psych.52.1.1

Bandura, A. (2007). Teoria spotecznego uczenia się [Social learning theory]. Warszawa: Wydawnictwo Naukowe PWN.

Bernard, L. C., Hutchison, S., Lavin, A., \& Pennington, P. (1996). Ego-strength, hardiness, self-esteem, self-efficacy, optimism, and maladjustment: Health-related personality constructs and the Big Five model of personality. Assessment, 3, 115-131. https://doi.org/10.1177/107319119600300203

Bonino, S., Graziano, F., Borghi, M., Marengo, D., Molinengo, G., \& Calandri, E. (2018). The Self-Efficacy in Multiple Sclerosis (SEMS) Scale: Development and validation with Rasch analysis. European Journal of Psychological Assessment, 34, 352-360. https://doi.org/10.1027/1015-5759/a000350 
Byra, S. (2011). Poczucie własnej skuteczności w kontekście radzenia sobie w sytuacjach trudnych kobiet i mężczyzn z nabytą niepełnosprawnością ruchową [Sense of self-efficacy in the context of coping in difficult situations among males and females with acquired motor disability]. Medycyna Ogólna i Nauki o Zdrowiu, 17, 127-134.

Calandri, E., Graziano, F., Borghi, M., \& Bonino, S. (2018). Depression, positive and negative affect, optimism and health-related quality of life in recently diagnosed multiple sclerosis patients: The role of identity, sense of coherence, and self-efficacy. Journal of Happiness Studies, 19, 277-295. https://doi.org/10.1007/s10902-016-9818-x

Calandri, E., Graziano, F., Borghi, M., \& Bonino, S. (2019). Young adults' adjustment to a recent diagnosis of multiple sclerosis: The role of identity satisfaction and self-efficacy. Disability and Health Journal, 12, 72-78. https://doi.org/10.1016/j. dhjo.2018.07.008

Carvalho, A. T., Veiga, A., Morgado, J., Tojal, R., Rocha, S., Vale, J., Sa, M. J., \& Timoteo, A. (2014). Multiple sclerosis and motherhood choice: an observational study in Portuguese women patients. Revista De Neurologia, 59, 537-542. https://doi. org/10.33588/rn.5912.2014332

Casey, B., Uszynski, M., Hayes, S., Motl, R., Gallagher, S., \& Coote, S. (2018). Do multiple sclerosis symptoms moderate the relationship between self-efficacy and physical activity in people with multiple sclerosis? Rehabilitation Psychology, 63, 104-110. https://doi.org/10.1037/rep0000190

Cassel, L., \& Suedfeld, P. (2006). Salutogenesis and autobiographical disclosure among Holocaust survivors. The Journal of Positive Psychology, 1, 212225. https://doi.org/10.1080/17439760600952919

Chroni, S., Hatzigeorgiadis, A., \& Theodorakis, Y. (2006). Onsite coping in novice climbers as a function of hardiness and self-efficacy. Annals of Leisure Research, 9, 139-154. https://doi.org/10.1080/ 11745398.2006 .10816426

Ciżkowicz, B. (2018). Omega McDonalda jako alternatywa dla alfa Cronbacha w szacowaniu rzetelności testu [McDonalds' omega as an alternative to Cronbach's alpha in scale score reliability estimation]. Polskie Forum Psychologiczne, 23, 311329. https://doi.org/10.14656/PFP20180206

Collin, C., Wade, D. T., Davies, S., \& Horne, V. (1988). The Barthel ADL Index: a reliability study. International Disability Studies, 10, 61-63. https://doi. org/10.3109/09638288809164103

Cross, A. H., Cross, K. A., \& Piccio, L. (2012). Update on multiple sclerosis, its diagnosis and treatments. Clinical Chemistry and Laboratory Medicine, 50, 1203-1210. https://doi.org/10.1515/cclm2011-0736

Członkowska, A. (2011). Stwardnienie rozsiane i inne zespoły demielinizacyjne [Multiple sclerosis and other demyelinating syndromes]. In W. Kozubski \& P. P. Liberski (Eds.), Neurologia. Podręcznik dla studentów medycyny [Neurology. Handbook for medical students] (pp. 499-523). Warszawa: Wydawnictwo Lekarskie PZWL.

Dymecka, J., \& Bidzan, M. (2018). Biomedical variables and adaptation to disease and health-related quality of life in Polish patients with MS. International Journal of Environmental Research and Public Health, 5, 2678. https://doi.org/10.3390/ijerph15122678

Dymecka, J., Bidzan-Bluma, I., Bidzan, M., BoruckaKotwica, A., Atroszko, P., \& Bidzan, M. (2020). Validity and reliability of the Polish adaptation of the Health-Related Hardiness Scale - the first confirmatory factor analysis results for a commonly used scale. Health Psychology Report, 8, 248-262. https://doi.org/10.5114/hpr.2020.95746

Dymecka, J., \& Gerymski, R. (2019). Niepełnosprawność a jakość życia pacjentów ze stwardnieniem rozsianym. Mediacyjna rola zapotrzebowania na wsparcie społeczne [Disability and the quality of life of patients with multiple sclerosis. Mediating role of the need for social support]. Cztowiek - Niepetnosprawność - Spoteczeństwo, 46, 63-78. https://doi.org/10.5604/01.3001.0013.7573

Dymecka, J., \& Gerymski, R. (2020). Acceptance of illness as a mediator of the relationship between neurological disability and health-related quality of life of people with multiple sclerosis. Neuropsychiatria i Neuropsychologia, 15, 13-20. https://doi. org/10.5114/nan.2020.93225

Eccles, F. J., \& Simpson, J. (2011). A review of the demographic, clinical and psychosocial correlates of perceived control in three chronic motor illnesses. Disability and Rehabilitation, 33, 1065-1088. https://doi.org/10.3109/09638288.2010.525287

Felton, B. J., Revenson, T. A., \& Hinrichsen, G. A. (1984). Stress and coping in the explanation of psychological adjustment among chronically ill adults. Social Science \& Medicine, 18, 889-898. https://doi.org/10.1016/0277-9536(84)90158-8

Ferrier, S., Dunlop, N., \& Blanchard, C. (2010). The role of outcome expectations and self-efficacy in explaining physical activity behaviors of individuals with multiple sclerosis. Behavioral Medicine, 36, 7-11. https://doi.org/10.1080/08964280903521354

Gilak, M., Zadehmohammadi, A., \& Bagheri, F. (2013). The relationship of resiliency and self-concept with self-efficacy of handicapped females: The mediating role of creativity. Developmental Psychology, 9 , 307-315.

Gerymski, R., \& Krok, D. (2019). Psychometric properties and validation of the Polish adaptation of the Light Triad Scale. Current Issues in Personality Psychology, 7, 341-354. https://doi.org/10.5114/ cipp.2019.92960

Gerymski, R., \& Krok, D. (2020). A Polish adaptation of the Multidimensional Existential Meaning 
Scale: Internal structure, reliability, and validity. Roczniki Psychologiczne, 23, 173-190. https://doi. org/10.18290/rpsych20232-4

Ghafari, S., Fallahi-Khoshknab, M., Nourozi, K., \& Mohammadi, E. (2015). Patients' experiences of adapting to multiple sclerosis: a qualitative study. Contemporary Nurse, 50, 36-49. https://doi.org/10. 1080/10376178.2015.1010252

Gold, R., \& Wolinsky, J. S. (2011). Pathophysiology of multiple sclerosis and the place of teriflunomide. Acta Neurologica Scandinavica, 124, 75-84. https:// doi.org/10.1111/j.1600-0404.2010.01444.x

Guicciardi, M., Carta, M., Pau, M., \& Cocco, E. (2019). The relationships between physical activity, selfefficacy, and quality of life in people with multiple sclerosis. Behavioral Sciences, 9, 121. https://doi. org/10.3390/bs9120121

Hashemi, L., Kooshesh, Z., \& Eskandari, H. (2015, August). Role of family communication patterns in development of hardiness and academic self-efficacy in adolescents. Proceedings of the Multidisciplinary Academic Conference, 1-8.

Hobart, J., Lamping, D., Fitzpatrick, R., Riazi, A., \& Thompson, A. (2001). The Multiple Sclerosis Impact Scale (MSIS-29): a new patient-based outcome measure. Brain, 124, 962-973. https://doi. org/10.1093/brain/124.5.962

Hyarat, S. Y., Subih, M., Rayan, A., Salami, I., \& Harb, A. (2019). Health related quality of life among patients with multiple sclerosis: The role of psychosocial adjustment to illness. Archives of Psychiatric Nursing, 33, 11-16. https://doi.org/10.1016/j.apnu.2018.08.006

Irvine, H., Davidson, C., Hoy, K., \& Lowe-Strong, A. (2009). Psychosocial adjustment to multiple sclerosis: exploration of identity redefinition. Disability and Rehabilitation, 31, 599-606. https://doi. org/10.1080/09638280802243286

Jamroz-Wiśniewska, A., Papuć, E., Bartosik-Psujek, H., Belniak, E., Mitosek-Szewczyk, K., \& Stelmasiak, Z. (2007). Analiza walidacyjna wybranych aspektów psychometrycznych polskiej wersji Skali Wpływu Stwardnienia Rozsianego na Jakość Życia Chorych (MSIS-29) [Validation of selected aspects of psychometry of the Polish version of the Multiple Sclerosis Impact Scale 29 (MSIS-29)]. Neurologia i Neurochirurgia Polska, 41, 215-222.

Juczyński, Z. (2001). Narzędzia w promocji i psychologii zdrowia [Measurement tools in the promotion and health psychology]. Warszawa: Pracownia Testów Psychologicznych Polskiego Towarzystwa Psychologicznego.

Juczyński, Z., \& Juczyński, A. (2012). „Chcieć to móc”, czyli o znaczeniu poczucia własnej skuteczności w modyfikacji zachowań związanych z piciem alkoholu [„,To want to be able" - the importance of self-efficacy in behaviour modification in regard to alcohol consumption]. Alkoholizm i Narkomania, 25, 215-227.
Kim, H. Y. (2013). Statistical notes for clinical researchers: Assessing normal distribution (2) using skewness and kurtosis. Restorative Dentistry \& Endodontics, 38, 52-54. https://doi.org/10.5395/ rde.2013.38.1.52

Kościelak, R. (2010). Poczucie umiejscowienia kontroli i przekonania o wtasnej skuteczności w zdrowiu $i$ chorobie [A sense of locating control and selfefficacy in health and disease]. Kraków: Oficyna Wydawnicza Impuls.

Kröninger-Jungaberle, H., \& Grevenstein, D. (2013). Development of salutogenetic factors in mental health - Antonovsky's sense of coherence and Bandura's self-efficacy related to Derogatis' symptom check list (SCL-90-R). Health and Quality of Life Outcomes, 11, 80. https://doi.org/10.1186/1477-7525-11-80

Krok, D., \& Gerymski, R. (2019). Self-efficacy as a mediator of the relationship between meaning in life and subjective well-being in cardiac patients. Current Issues in Personality Psychology, 7, 242-251. https://doi.org/10.5114/cipp.2019.89168

Kulik, M. M. (2008). Cierpienie, które przerasta, czyli o wypaleniu lekarzy pracujących z ludźmi przewlekle chorymi [The suffering which goes beyond strengths - burnout syndrome of the doctors who work with chronically ill people]. Studia z Psychologii w KUL, 15, 81-112.

Lawshe, C. H. (1975). A quantitative approach to content validity. Personnel Psychology, 28, 563-575. https://doi.org/10.1111/j.1744-6570.1975.tb01393.x

Li, S. M., \& Shiu, A. T. (2008). Sense of coherence and diabetes psychosocial self-efficacy of members of a peer-led organisation in Hong Kong. Journal of Clinical Nursing, 17(11), 1526-1528. https://doi. org/10.1111/j.1365-2702.2007.02062.x

Luszczynska, A., Scholz, U., \& Schwarzer, R. (2005). The General Self-Efficacy Scale: Multicultural validation studies. The Journal of Psychology, 139, 439457. https://doi.org/10.3200/JRLP.139.5.439-457

May, K. M., Sowa, C. J., \& Niles, S. G. (1993). Family environments as predictors of personality hardiness and self-efficacy. The Family Journal, 1, 131135. https://doi.org/10.1177/1066480793012003

McReynolds, C. J., Koch, L. C., \& Rumrill, P. D. (1999). Psychosocial adjustment to multiple sclerosis: implications for rehabilitation professionals. Journal of Vocational Rehabilitation, 12, 83-91.

Miciuk, Ł., Jankowski, T., \& Oleś, P. (2016). Incremental validity of positive orientation: Predictive efficiency beyond the five-factor model. Health Psychology Report, 4, 294-302. https://doi.org/10.5114/ hpr.2016.59895

Milioni, M., Alessandri, G., Eisenberg, N., Castellani, V., Zuffianò, A., Vecchione, M., \& Caprara, G. V. (2015). Reciprocal relations between emotional self-efficacy beliefs and ego-resiliency across time. Journal of Personality, 83, 552-563. https://doi. org/10.1111/jopy. 12131 
Mitchell, A. J., Benito-León, J., Morales González, J. M., \& Rivera-Navarro, J. (2005). Quality of life and its assessment in multiple sclerosis: Integrating physical and psychological components of wellbeing. The Lancet. Neurology, 4, 556-566. https:// doi.org/10.1016/S1474-4422(05)70166-6

Morris, K. S., McAuley, E., \& Motl, R. W. (2008). Selfefficacy and environmental correlates of physical activity among older women and women with multiple sclerosis. Health Education Research, 23, 744-752. https://doi.org/10.1093/her/cym067

Motl, R. W., McAuley, E., Wynn, D., Sandroff, B., \& Suh, Y. (2013). Physical activity, self-efficacy, and health-related quality of life in persons with multiple sclerosis: Analysis of associations between individual-level changes over one year. Quality of Life Research, 22, 253-261. https://doi.org/10.1007/ s11136-012-0149-z

Motl, R. W., \& Snook, E. M. (2008). Physical activity, self-efficacy, and quality of life in multiple sclerosis. Annals of Behavioral Medicine, 35, 111-115. https://doi.org/10.1007/s12160-007-9006-7

Nowaczyk, N., \& Cierpiałkowska, L. (2016). Psychological profiles of patients with multiple sclerosis based on Hobfoll's conservation of resources theory. Health Psychology Report, 4, 332-339. https:// doi.org/10.5114/hpr.2016.59990

Ogińska-Bulik, N., \& Juczyński, Z. (2008). Skala Pomiaru Prężności (SPP-25) [The Resilience Assessment Scale (RAS-25)]. Nowiny Psychologiczne, 3, 39-56.

Ogińska-Bulik, N., \& Juczyński, Z. (2010). Osobowość, stres a zdrowie [Personality, stress and health]. Warszawa: Difin.

Oleś, P. (2003). Wprowadzenie do psychologii osobowości [Introduction to personality psychology]. Warszawa: Scholar.

Oman, R. F., \& Duncan, T. E. (1995). Women and exercise: an investigation of the roles of social support, self-efficacy, and hardiness. Medicine, Exercise, Nutrition \& Health, 4, 306-315.

Pasikowski, T. (2001). Kwestionariusz Poczucia Koherencji dla Dorosłych (SOC-29) [Sense of Coherence Questionnaire for Adults]. In H. Sęk \& T. Pasikowski (Eds.), Zdrowie - stres - zasoby. O znaczeniu poczucia koherencji dla zdrowia [Health - Stress - Resources. On the importance of the sense of coherence for health] (pp. 71-86). Poznań: Wydawnictwo Humaniora.

Pearlin, L. I., \& Schooler, C. (1978). The structure of coping. Journal of Health and Social Behavior, 1, 2-21.

Pervin, L. A., \& John, O. P. (2001). Osobowość - teoria $i$ badania [Personality - theory and research]. Kraków: Wydawnictwo Uniwersytetu Jagiellońskiego.

Podlecka-Piętowska, A. (2010). Co to jest stwardnienie rozsiane? [What is multiple sclerosis?]. In
B. Zakrzewska-Pniewska (Ed.), Stwardnienie rozsiane: nowy poradnik dla pacjenta [Multiple sclerosis: a new patient guide] (pp. 7-22). Poznań: Termedia.

Pollock, S. E. (1986). Human responses to chronic illness physiologic and psychosocial adaptation. Nursing Research, 35, 90-95.

Posadzki, P., Stockl, A., Musonda, P., \& Tsouroufli, M. (2010). A mixed-method approach to sense of coherence, health behaviors, self-efficacy and optimism: Towards the operationalization of positive health attitudes. Scandinavian Journal of Psychology, 51, 246-252. https://doi.org/10.1111/j.14679450.2009.00764.x

Rankin, J. (1957). Cerebral vascular accidents in patients over the age of 60: II. Prognosis. Scottish Medical Journal, 2, 200-215. https://doi. org/10.1177/003693305700200504

Rosenberg, M. (1965). Society and the adolescent selfimage. Princeton, NJ: Princeton University Press.

Schmitt, M. M., Goverover, Y., Deluca, J., \& Chiaravalloti, N. (2014). Self-efficacy as a predictor of selfreported physical, cognitive, and social functioning in multiple sclerosis. Rehabilitation Psychology, 59, 27-34. https://doi.org/10.1037/a0035288

Schwartz, C. E., Coulthard-Morris, L., Zeng, Q., \& Retzlaff, P. (1996). Measuring self-efficacy in people with multiple sclerosis: a validation study. Archives of Physical Medicine and Rehabilitation, 77, 394-398. https://doi.org/10.1016/s00039993(96)90091-x

Schwarzer, R. (1997). Poczucie własnej skuteczności w podejmowaniu i kontynuacji zachowań zdrowotnych. Dotychczasowe podejścia teoretyczne i nowy model [Self-efficacy in undertaking and continuing health behaviors. Previous theoretical approaches and a new model]. In I. Heszen-Niejodek \& H. Sęk (Eds.), Psychologia zdrowia [Health psychology] (pp. 175-205). Warszawa: PWN.

Seebacher, B., Mills, R. J., Reindl, M., Zamarian, L., Kuisma, R., Kircher, S., Brenneis, C., Rainer Ehling, R., \& Deisenhammer, F. (2019). German translation, cultural adaption and validation of the unidimensional self-efficacy scale for multiple sclerosis: a study protocol. BMJ Open, 9, e029565. https://doi.org/10.1136/bmjopen-2019-029565

Selmaj, K. (2006). Stwardnienie rozsiane [Multiple sclerosis]. Poznań: Termedia.

Sikes, E. M., Cederberg, K. L., Baird, J. F., Sandroff, B. M., \& Motl, R. W. (2019). Self-efficacy and walking performance across the lifespan among adults with multiple sclerosis. Neurodegenerative Disease Management, 9, 267-275. https://doi.org/ 10.2217/nmt-2019-0007

Tomczak, K. (2009). Style radzenia sobie w sytuacji stresowej, przekonanie o własnej skuteczności, nadzieja na sukces u studentów rozpoczynających i kończących studia [Style of coping with stress, 
conviction with self-efficacy and hope for success amongst first-year and last-year university students]. Psychoterapia, 2, 67-79.

Trap, R., Rejkjær, L., \& Hansen, E. H. (2015). Empirical relations between sense of coherence and self-efficacy, National Danish Survey. Health Promotion International, 31, 635-643. https://doi.org/10.1093/ heapro/dav052

Vukusic, S., \& Marignier, R. (2015). Multiple sclerosis and pregnancy in the 'treatment era'. $\mathrm{Na}$ ture Reviews. Neurology, 11, 280-289. https://doi. org/10.1038/nrneurol.2015.53

Wassem, R. (1992). Self-efficacy as a predictor of adjustment to multiple sclerosis. The Journal of Neuroscience Nursing, 25, 224-229. https://doi. org/10.1097/01376517-199208000-00010

Zakrzewska-Pniewska, B. (2010). Podstawy diagnostyki i leczenia stwardnienia rozsianego [Fundamentals of diagnosis and treatment of multiple sclerosis]. Gdańsk: Via Medica.

Ziarko, M. (2014). Zmaganie się ze stresem choroby przewlektej [Struggling with the stress of a chronic disease]. Poznań: Wydawnictwo Naukowe Wydziału Nauk Społecznych UAM. 
APPENDIX

\section{LIVERPOOLSKA SKALA POCZUCIA WŁASNEJ SKUTECZNOŚCI}

(adaptacja: Dymecka, Gerymski, \& Bidzan, 2020)

Pomyśl o tym, jak czułeś się w ciągu ostatniego tygodnia. Przeczytaj poniższe stwierdzenia i wskaż, w jaki sposób zgadzasz się z nimi, zakreślając jedną odpowiedź na każde pytanie.

1 - zdecydowanie się zgadzam

2 - zgadzam się

3 - nie zgadzam się

4 - zdecydowanie się nie zgadzam

1. Odkąd moja diagnoza została potwierdzona, moje życie jest otoczone wieloma trudnościami, których nie kontroluję.

2. Czuję, że mam kontrolę nad swoim życiem.*

3. Polegam na innych, aby pomogli mi w podejmowaniu decyzji.

4. Czasami czuję, że moje SM kontroluje moje życie.

$\begin{array}{llll}1 & 2 & 3 & 4\end{array}$

5. Często czuję się bezradny, gdy próbuję sobie poradzić z moimi trudnościami.

6. To, jak SM będzie na mnie wpływało w przyszłości, zależy głównie ode mnie.*

7. Martwię się o to, jak będę sobie radził w przyszłości.

8. Pomimo moich trudności ciągle radzę sobie z codziennym życiem.*

$\begin{array}{llll}1 & 2 & 3 & 4\end{array}$

$\begin{array}{llll}1 & 2 & 3 & 4\end{array}$

$\begin{array}{llll}1 & 2 & 3 & 4\end{array}$

$\begin{array}{llll}1 & 2 & 3 & 4\end{array}$

9. Naprawdę nie ma sposobu, w jaki mógłbym sobie poradzić z niektórymi problemami, $\begin{array}{lllll}1 & 2 & 3 & 4\end{array}$ jakie mam z moim SM.

10. Pomimo mojego SM mogę zrobić wszystko, czego tylko pragnę.*

11. Jestem przekonany, że mogę pokonać moje trudności. ${ }^{*}$

$\begin{array}{llll}1 & 2 & 3 & 4\end{array}$

Klucz:

*item odwrócony

Kontrola: $1,2^{*}, 3,4,5,6^{*}$

Czynnik osobisty: 7, 8*, 9, 10*, 11* 